\title{
Spectral studies of transition metal complexes with 25, 26 dioxo1,6,12,17,23,24 hexaazacyclohexacosa 1,5,12,16 tetraene macrocyclic ligand $(\mathrm{L})$
}

\author{
Sulekh Chandra ${ }^{*}$, Poonam Pipil ${ }^{2}$ \\ ${ }^{1}$ Department of Chemistry, Zakir Husain Delhi College, University of Delhi, New Delhi, India \\ ${ }^{2}$ Department of Chemistry, Rajdhani College, University of Delhi, New Delhi, India \\ Email: ${ }^{*}$ schandra_00@yahoo.com,www.poonam.pipil@gmail.com
}

Received 14 June 2013; revised 14 July 2013; accepted 21 July 2013

Copyright (C) 2013 Sulekh Chandra, Poonam Pipil. This is an open access article distributed under the Creative Commons Attribution License, which permits unrestricted use, distribution, and reproduction in any medium, provided the original work is properly cited.

\begin{abstract}
$\mathrm{Mn}(\mathrm{II}), \mathrm{Co}(\mathrm{II}), \mathrm{Ni}(\mathrm{II})$ and $\mathrm{Cu}(\mathrm{II})$ complexes with this ligand (L) i.e. 25, 26 dioxo1,6,12,17,23,24 hexaazacyclohexacosa1,5,12,16 tetraene have been prepared. All the complexes were characterized by elemental analysis, molar conductance measurements, magnetic susceptibility measurements, mass, i.r. electronic, and e.p.r. spectral studies. The molar conductance measurements in DMF indicate that the Mn(II), Co(II), and $\mathrm{Cu}(\mathrm{II})$ are non-electrolyte whereas the complexes of $\mathrm{Ni}(\mathrm{II})$ are electrolyte. Thus, these complexes may be formulated as $\left[\mathrm{M}(\mathrm{L}) \mathrm{X}_{2}\right]$ and $[\mathrm{Ni}(\mathrm{L})] \mathrm{X}_{2}($ where $\mathrm{M}=$ $\mathrm{Mn}(\mathrm{II}), \mathrm{Co}(\mathrm{II})$ and $\mathrm{Cu}(\mathrm{II})$ and $\mathrm{X}=\mathrm{C1}^{-}$and $\mathrm{NO}_{3}^{-}$). All the complexes are of the high spin type expected $\mathrm{Ni}$ (II) complexes which are diamagnetic. On the basis of spectral studies, an octahedral geometry may be assigned of $\mathrm{Mn}$ (II) and Co(II). Square planar is for $\mathrm{Ni}$ (II) complexes, and tetragonal geometry for $\mathrm{Cu}$ (II) complexes.
\end{abstract}

Keywords: Mass; IR; Magnetic Moment; Electronic EPR; X-Ray Diffraction Studies

\section{INTRODUCTION}

Schiff bases are widely studied because of increasing recognition in biological system [1] e.g. antimicrobial, antiviral, antifungal, antitumour and other biological activities particularly with first row of transition metal complexes [2-9]. Macrocyclic compounds are similar in structure and reactions to many naturally occurring compounds, Which are known to exhibit selective cation complexation $[10,11]$. The chemical properties of macrocyclic complexes can be turned to force metal ions

${ }^{*}$ Corresponding author. to adopt unusal coordination geometry. Transition metal macrocyclic complexes have received much attention as an active part of metalloenzymes [12] as biomimic model compounds [13] due to their resemblence with natural proteins like hemerythrin and enzymes. Synthesis of transition metal complexes of new aza macrocycles with different cavity sizes donor types, ring substituents etc. under different experimental conditions have resulted in a large number and variety of compounds $[14,15]$. Because of the numerous areas of chemistry where aza macrocyclic complexes have found a niche, the preparation of new macrocyclic ligands with ever more elaborate structures is also a vital area of research. In view of the above applications, the synthesis and characterization of transition metal complexes with such ligand is highly desirable. In this paper we report the synthesis and characterization of transition metal complexes with 25,26 dioxo1,6,12,17,23,24 hexaaza cyclohexaneosa 1,5,12,16 tetraene macrocyclic ligand [L]. (Figure 1).

\section{CHEMISTRY}

All the chemicals used were of Anala R grade, and were purchased from Aldrich. Metal salts were purchased from E. Merck and were used as received. All solvents used were of standard/spectroscopic grade.

\subsection{Synthesis of Complexes}

All the complexes were prepared by template method. An ethanolic solution of diethylenetriamine $[10 \mathrm{~mL}]$ and glutaricanhydride $(10 \mathrm{~mL})$ were mixed. To this soluction the ehtanolic solution of metal salt $(0.001 \mathrm{~mol})$ was added. The resulting solution was boiled under refluxed for six hours. The solution was then concentrated upto half of its volume under reduced pressure. On cooling 
the solution is precipitated out. It was filtered, washed with cold ethanol and dried over $\mathrm{P}_{4} \mathrm{O}_{10}$ under vaccum.

\subsection{Physical Measurements}

The C, H, and N were analyzed on a Carlo-Erba 1106 elemental analyzer. Molar conductance was measured on the ELICO (CM82T) conductivity bridge. Magnetic susceptibility was measured at room temperature on a Gouy-balance using $\mathrm{CuSO}_{4} \cdot 5 \mathrm{H}_{2} \mathrm{O}$ as a callibrant Electron-impact mass spectra were recorded on JEOL, JMS, DX-303 mass spectrometer, IR spectra were recorded on a Perkin-Elmer 137 instrument in Csl pellets. EPR spectra of the complexes were recorded as polycrystalline sample and in the DMF solution, at liquid nitrogen temperature for $\mathrm{Co}$ (II) and at room temperature for $\mathrm{Mn}$ (II) and $\mathrm{Cu}$ (II) complexes on E4-EPR spectrometer using the $\mathrm{DPPH}$ as the g-marker.

\section{RESULTS AND DISCUSSION}

Complexes: On the basis of elemental analysis, the complexes were found to have the composition as shown in Table 1.

The molar conductance measurement of the complexes in DMF correspond to be nonelectrolytic nature for $\mathrm{Mn}(\mathrm{II}), \mathrm{Co}(\mathrm{II})$ and $\mathrm{Cu}(\mathrm{II})$ while 1:2 electrolytes for $\mathrm{Ni}$ (II) complexes. Thus, these complexes may be formulated as $\left[\mathrm{M}(\mathrm{L}) \mathrm{X}_{2}\right]$ and $[\mathrm{Ni}(\mathrm{L})] \mathrm{X}_{2}$ (where $\mathrm{M}=\mathrm{Mn}(\mathrm{II})$,
$\mathrm{Co}(\mathrm{II})$, and $\mathrm{Cu}(\mathrm{II})$ and $\mathrm{X}=\mathrm{Cl}^{-}$and $\mathrm{NO}_{3}^{-}$). In the IR spectra of complexes, the shifting in lower side of a band $[\mathrm{v}(\mathrm{N}-\mathrm{H})]$ and the band of amides II and III, suggest the coordination through nitrogen of $-\mathrm{NH}$ group $\left(\mathrm{N}_{4}\right)$.

\section{1. i.r. Spectra of the Complexes}

The presence of the obsorption bands at 1410 - 1421, 1299 - 1319 and $1010-1031 \mathrm{~cm}^{-1}$, in the i.r. spectra Figures 2(a)-(c) of the $\mathrm{Mn}(\mathrm{II}), \mathrm{Co}(\mathrm{II})$ and $\mathrm{Cu}(\mathrm{II})$ of nitrato complexes suggest the both nitrate groups are coordinated to the central metal ion in a unidentate fashion [16-18]. The Ni(II) nitrato complex exhibits a sharp strong peak at $1387 \mathrm{~cm}^{-1}$, which is in favour of an un-cordinated nitrate group [16,17].

\subsubsection{Manganese(II) Complexes}

The magnetic moment recorded at room temperature lies in the range 5.90 - 5.96 B.M. corresponding to five unpaired electrons. Electronic spectra of Mn(II) complexes in DMSO solution display four weak intensity adsorption bands (Table 2) in the 15,870 - 16,743 region $(\varepsilon=24$ $\left.261 \cdot \mathrm{mol}^{-1} \cdot \mathrm{cm}^{-1}\right), 20,356-21,685\left(\varepsilon=33-361 \cdot \mathrm{mol}^{-1}\right.$ $\left.\mathrm{cm}^{-1}\right) 24,787-27,006\left(\varepsilon=61-641 \cdot \mathrm{mol}^{-1} \cdot \mathrm{cm}^{-1}\right)$. These bands may be assigned to the transitions, ${ }^{6} \mathrm{~A}_{1 \mathrm{~g}}-{ }^{4} \mathrm{~A}_{1 \mathrm{~g}}\left({ }^{4} \mathrm{G}\right)$, ${ }^{6} \mathrm{~A}_{1 \mathrm{~g}}-{ }^{4} \mathrm{E}_{\mathrm{g}},{ }^{6} \mathrm{~A}_{1 \mathrm{~g}}\left({ }^{4} \mathrm{G}\right)(10 \mathrm{~B}+5 \mathrm{C}),{ }^{6} \mathrm{~A}_{1 \mathrm{~g}}-{ }^{4} \mathrm{E}_{\mathrm{g}}\left({ }^{4} \mathrm{D}\right)(17 \mathrm{~B}+$ 5C) and ${ }^{6} \mathrm{~A}_{1 \mathrm{~g}}-{ }^{4} \mathrm{~T}_{1 \mathrm{~g}}\left({ }^{4} \mathrm{P}\right)$, respectively [19].

The e.p.r. spectra were recorded at room temperature

Table 1. Molar conductance and elemental analysis data of complexes.

\begin{tabular}{|c|c|c|c|c|c|c|c|c|}
\hline \multirow[t]{2}{*}{ Complex } & \multirow[t]{2}{*}{ Colour } & \multirow{2}{*}{$\begin{array}{c}\text { Molar } \\
\text { Conductance } \\
\left(\Omega^{1} \cdot \mathrm{cm}^{-1} \cdot \mathrm{mol}^{-1}\right)\end{array}$} & \multirow{2}{*}{$\begin{array}{c}\% \\
\text { Yield }\end{array}$} & \multicolumn{4}{|c|}{$\begin{array}{c}\text { Elemental Analysis Data } \\
\text { Calculated (Found) \% }\end{array}$} & \multirow{2}{*}{$\begin{array}{l}\text { M. Pt } \\
\left({ }^{\circ} \mathrm{C}\right)\end{array}$} \\
\hline & & & & C & $\mathbf{H}$ & $\mathbf{N}$ & Metal & \\
\hline $\begin{array}{c}{\left[\mathrm{Mn}(\mathrm{L}) \mathrm{Cl}_{2}\right]} \\
\mathrm{C}_{20} \mathrm{H}_{18} \mathrm{MnN}_{6} \mathrm{~S}_{2} \mathrm{Cl}_{2}\end{array}$ & Brown & 02 & 69 & $\begin{array}{c}45.0 \\
(45.1)\end{array}$ & $\begin{array}{c}3.3 \\
(3.4)\end{array}$ & $\begin{array}{c}15.6 \\
(15.8)\end{array}$ & $\begin{array}{c}10.5 \\
(10.3)\end{array}$ & 280 \\
\hline $\begin{array}{c}{\left[\mathrm{Mn}(\mathrm{L})\left(\mathrm{NO}_{3}\right)_{2}\right]} \\
\mathrm{C}_{20} \mathrm{H}_{18} \mathrm{MnN}_{8} \mathrm{~S}_{2} \mathrm{O}_{6}\end{array}$ & $\begin{array}{l}\text { Light } \\
\text { Brown }\end{array}$ & 09 & 66 & $\begin{array}{c}41.0 \\
(40.8)\end{array}$ & $\begin{array}{c}3.1 \\
(3.0)\end{array}$ & $\begin{array}{c}19.0 \\
(19.1)\end{array}$ & $\begin{array}{c}9.2 \\
(9.4)\end{array}$ & 288 \\
\hline $\begin{array}{c}{\left[\mathrm{Co}(\mathrm{L})\left(\mathrm{NO}_{3}\right)_{2}\right]} \\
\mathrm{C}_{20} \mathrm{H}_{18} \mathrm{CoN}_{6} \mathrm{~S}_{2} \mathrm{Cl}_{2}\end{array}$ & Pink & 10 & 65 & $\begin{array}{c}44.6 \\
(44.4)\end{array}$ & $\begin{array}{r}3.4 \\
(3.3)\end{array}$ & $\begin{array}{c}15.6 \\
(15.7)\end{array}$ & $\begin{array}{c}11.3 \\
(11.0)\end{array}$ & 290 \\
\hline $\begin{array}{c}{\left[\mathrm{Co}(\mathrm{L})\left(\mathrm{NO}_{3}\right)_{2}\right]} \\
\mathrm{C}_{20} \mathrm{H}_{18} \mathrm{CoN}_{8} \mathrm{~S}_{2} \mathrm{O}_{6}\end{array}$ & Pink & 08 & 61 & $\begin{array}{c}40.5 \\
(40.7)\end{array}$ & $\begin{array}{c}3.1 \\
(3.2)\end{array}$ & $\begin{array}{c}18.8 \\
(19.0)\end{array}$ & $\begin{array}{c}9.9 \\
(10.0)\end{array}$ & 299 \\
\hline $\begin{array}{c}{\left[\mathrm{Ni}(\mathrm{L}) \mathrm{Cl}_{2}\right]} \\
\mathrm{C}_{20} \mathrm{H}_{18} \mathrm{NiN}_{2} \mathrm{~S}_{2} \mathrm{Cl}_{2}\end{array}$ & Red & 158 & 64 & $\begin{array}{c}44.6 \\
(44.2)\end{array}$ & $\begin{array}{c}3.4 \\
(3.6)\end{array}$ & $\begin{array}{c}15.5 \\
(15.7)\end{array}$ & $\begin{array}{c}11.2 \\
(10.0)\end{array}$ & 298 \\
\hline $\begin{array}{c}{\left[\mathrm{Ni}(\mathrm{L})\left(\mathrm{NO}_{3}\right)_{2}\right]} \\
\mathrm{C}_{20} \mathrm{H}_{18} \mathrm{NiN}_{2} \mathrm{~S}_{2} \mathrm{O}_{6}\end{array}$ & Orange & 146 & 60 & $\begin{array}{c}40.2 \\
(40.5)\end{array}$ & $\begin{array}{c}3.1 \\
(3.5)\end{array}$ & $\begin{array}{c}18.8 \\
(19.0)\end{array}$ & $\begin{array}{c}9.8 \\
(10.0)\end{array}$ & 297 \\
\hline $\begin{array}{c}{[\mathrm{Cu}(\mathrm{L}) \mathrm{Cl} 2]} \\
\mathrm{C}_{20} \mathrm{H}_{18} \mathrm{CuN}_{6} \mathrm{~S}_{2} \mathrm{Cl}_{2}\end{array}$ & Blue & 06 & 62 & $\begin{array}{c}44.1 \\
(44.5)\end{array}$ & $\begin{array}{c}3.3 \\
(3.2)\end{array}$ & $\begin{array}{c}15.8 \\
(15.5)\end{array}$ & $\begin{array}{c}11.6 \\
(11.8)\end{array}$ & 288 \\
\hline $\begin{array}{c}{\left[\mathrm{Cu}(\mathrm{L})\left(\mathrm{NO}_{3}\right)_{2}\right]} \\
\mathrm{C}_{20} \mathrm{H}_{18} \mathrm{CuN}_{8} \mathrm{~S}_{2} \mathrm{O}_{6}\end{array}$ & Shiny Blue & 09 & 61 & $\begin{array}{c}40.2 \\
(40.4)\end{array}$ & $\begin{array}{c}3.0 \\
(2.9)\end{array}$ & $\begin{array}{c}18.8 \\
(18.9)\end{array}$ & $\begin{array}{c}10.9 \\
(10.8)\end{array}$ & 290 \\
\hline
\end{tabular}


Table 2. Magnetic moments and electronic spectral data of the complexes.

\begin{tabular}{|c|c|c|c|}
\hline Complex & $\lambda \operatorname{Max}\left(\mathrm{cm}^{-1}\right)$ & $\mu$ eff (B.M.) & $\varepsilon\left(\mathrm{L} \mathrm{mol}^{-1} \cdot \mathrm{cm}^{-1}\right)$ \\
\hline \multirow{2}{*}{$\mathbf{M n}(\mathbf{L}) \mathbf{C l}_{2}$}$]$ & $15,872,21,685$ & \multirow{2}{*}{5.90} & \multirow{2}{*}{$24,36,61,135$} \\
\hline & $24,785,38,217$ & & \\
\hline$\left[\mathrm{Mn}(\mathrm{L})\left(\mathrm{NO}_{3}\right)_{2}\right]$ & $\begin{array}{l}16,743,20,356 \\
27,006,35,426\end{array}$ & 5.96 & $26,33,64,128$ \\
\hline$\left[\mathrm{Co}(\mathrm{L}) \mathrm{Cl}_{2}\right]$ & $\begin{array}{c}9896,14,906, \\
17,341,39,046\end{array}$ & 4.85 & $56,67,82,157$ \\
\hline$\left[\mathrm{Co}(\mathrm{L})\left(\mathrm{NO}_{3}\right)_{2}\right]$ & $\begin{array}{c}9510,14,285 \\
18,645,38,819\end{array}$ & 4.76 & $55,65,84,154$ \\
\hline$\left.[\mathrm{Ni}(\mathrm{L})] \mathrm{Cl}_{2}\right)$ & $\begin{array}{c}1651,22,088 \\
30,114\end{array}$ & Diamagnetic & $52,92,132$ \\
\hline$\left.[\mathrm{Ni}(\mathrm{L})]\left(\mathrm{NO}_{3}\right)_{2}\right)$ & $\begin{array}{c}15,811,20,983 \\
28,547\end{array}$ & Diamagnetic & $51,90,128$ \\
\hline$\left[\mathrm{Cu}(\mathrm{L}) \mathrm{Cl}_{2}\right]$ & $\begin{array}{c}9983,15,991 \\
28,057\end{array}$ & 1.96 & $48,58,149$ \\
\hline$\left[\mathrm{Cu}(\mathrm{L})\left(\mathrm{NO}_{3}\right)_{2}\right]$ & $\begin{array}{c}10,560,16,384 \\
29,514\end{array}$ & 1.90 & $49,58,151$ \\
\hline
\end{tabular}

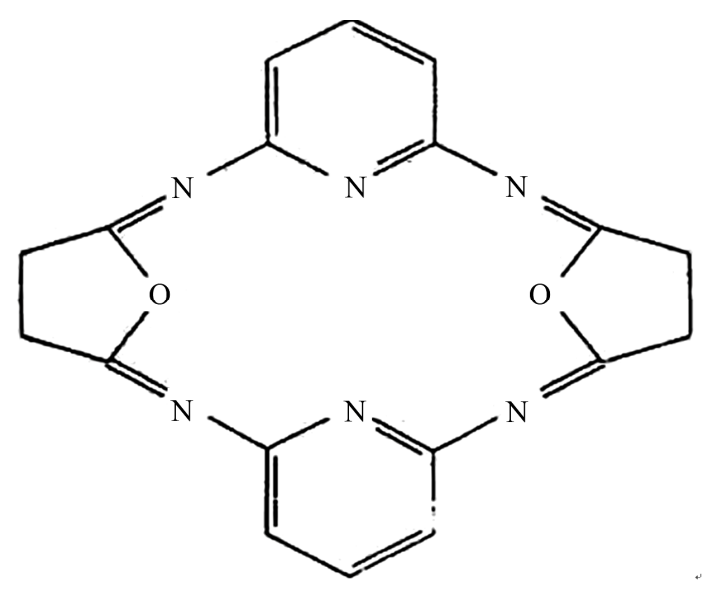

Figure 1. Structure of ligand.

as polycrystalline samples and in DMSO solution. The polycrystalline spectra give an isotropic signal centered at $2.04-2.16$. The spectra recorded in DMSO solution gives well-resolved six line spectra due to the hyperfine interaction between the unpaired electrons with the ${ }^{55} \mathrm{Mn}$ nuclear $(1=5 / 2)$.

\subsubsection{Cobalt(II) Complexes}

At room temperature the magnetic moment measurements of cobalt(II) complexes lies in the range 4.76 4.85 B.M corresponding to three unpaired electron (Table 2). The electronic spectra of all the cobalt(II) complexes Figure 3 exhibit aborption in the region 6510 $9896\left(\varepsilon=55-65 \mathrm{~L} \cdot \mathrm{mol}^{-1} \cdot \mathrm{cm}^{-1}\right), 14,285-14,906(\varepsilon=65-$ $\left.67 \mathrm{~m} \cdot \mathrm{mol}^{-1} \cdot \mathrm{cm}^{-1}\right), 17341-18645\left(\varepsilon=82-74 \mathrm{~L} \cdot \mathrm{mol}^{-1} \cdot \mathrm{cm}^{-1}\right)$ and $39,046-38,819 \mathrm{~cm}^{-1}\left(\varepsilon=154-157 \mathrm{~L} \cdot \mathrm{mol} \cdot \mathrm{cm}^{-1}\right)$. These bands may be assigned to the transitions: ${ }^{4} \mathrm{~T}_{1 \mathrm{~g}}(\mathrm{~F})$ $-{ }^{4} \mathrm{~T}_{2 \mathrm{~g}}(\mathrm{~F})\left(\mathrm{v}_{1}\right),{ }_{4} \mathrm{~T}_{1 \mathrm{~g}}-{ }^{4} \mathrm{~A}_{2 \mathrm{~g}}\left(\mathrm{v}_{2}\right)$ and ${ }^{4} \mathrm{~T}_{1 \mathrm{~g}}(\mathrm{~F})-{ }^{4} \mathrm{~T}_{1 \mathrm{~g}}(\mathrm{P})\left(\mathrm{v}_{3}\right)$, respectively [20].

It is difficult to make the assignments for the fourth band and it may be considered as a charge transfer band. The position of these suggests an octahedral environment around the cobalt (II) ion.

The e.p.r. spectra of the Co(II) complexes were recorded as polycrystalline samples and in DMSO solution at liquid nitrogen temperature (LNT).

The g-values were found to be almost the same in both cases in polycrystalline samples as well as in the solution, (Table 3).

It indicates that the complexes have the same geometry in the solid as well as in solution. The large deviation in g-values, in the e.p.r. spectra, from the spin only value $(\mathrm{g}=2.0023)$ is due to the large angular momentum contribution.

\subsubsection{Nickel(II) Complexes}

At room temperature these complexes show the diamagnetic behavior, indicating the square planar environment around the $\mathrm{Ni}(\mathrm{II})$ ion.

The electronic spectra of Figure 4 the Ni(II) complexes, exhibit three absorption bands in the range 15,812 $16,510\left(\varepsilon=51-53 \mathrm{~L} \cdot \mathrm{mol}^{-1} \cdot \mathrm{cm}^{-1}\right), 20,983-22,088(\varepsilon=$ $\left.90-92 \mathrm{~L} \cdot \mathrm{mol}^{-1} \cdot \mathrm{cm}^{-1}\right)$ and $28,547-30,114 \mathrm{~cm}^{-1}(\varepsilon=128$ - $\left.132 \mathrm{~L} \cdot \mathrm{mol}^{-1} \cdot \mathrm{cm}^{-1}\right)$. An examination of these bands indicates that the complexes have square planar geometry. These bands may be assigned to the three spin allowed 


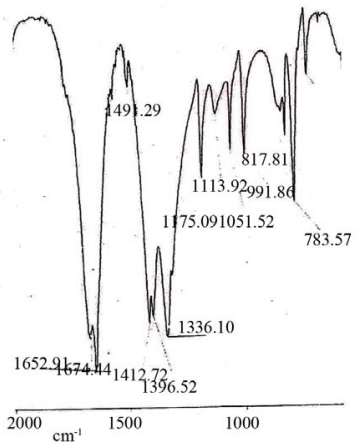

(a)

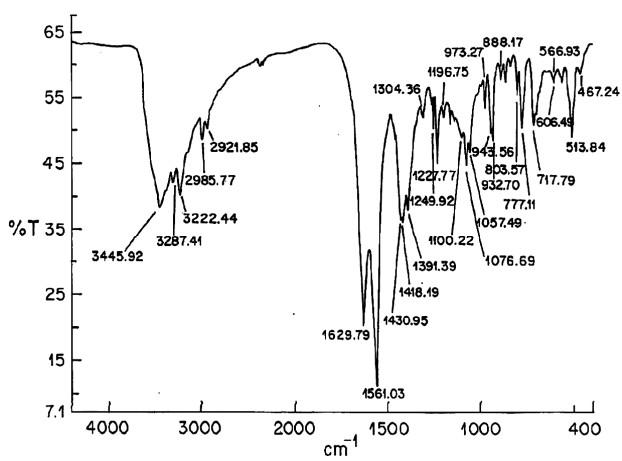

(b)

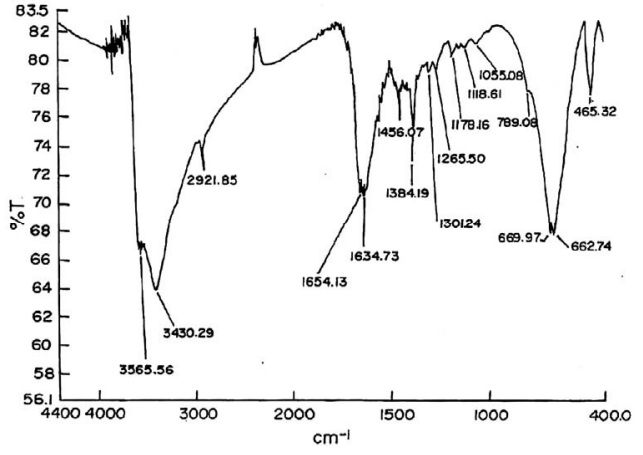

(c)

Figure 2. (a) IR Spectrum of $\left[\mathrm{Co}\left(\mathrm{L}^{5}\right)\left(\mathrm{NO}_{3}\right)_{2}\right]$; IR Spectrum of $\left[\mathrm{Ni}\left(\mathrm{L}^{5}\right)\left(\mathrm{NO}_{3}\right)_{2}\right]$; IR Spectrum of $\left[\mathrm{Cu}\left(\mathrm{L}^{5}\right)\left(\mathrm{NO}_{3}\right)_{2}\right]$.

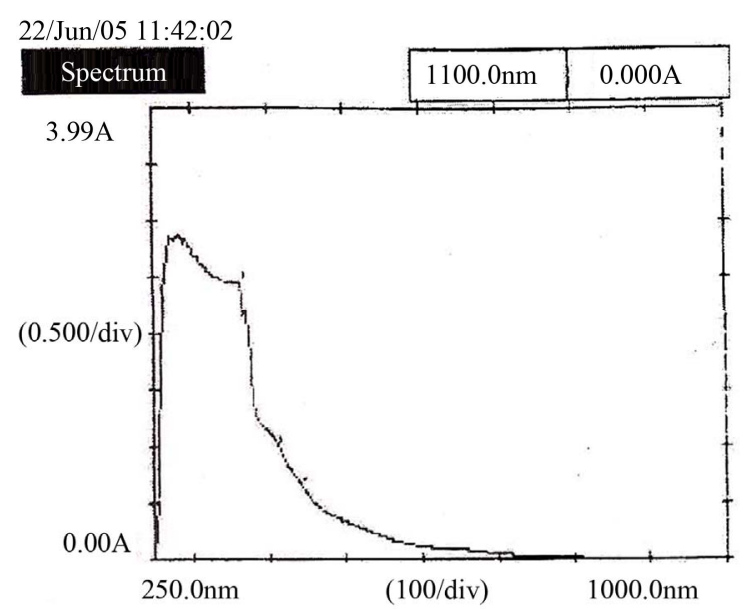

Figure 3. UV Spectrum of $\left[\mathrm{Co}\left(\mathrm{L}^{5}\right)\left(\mathrm{NO}_{3}\right)_{2}\right]$.

transitions: ${ }^{1} \mathrm{~A}_{1 \mathrm{~g}}$ (D) $\left(\mathrm{v}_{1}\right),{ }^{1} \mathrm{~A}_{1 \mathrm{~g}}(\mathrm{D})-{ }^{1} \mathrm{~B}_{2 \mathrm{~g}}(\mathrm{G})\left(\mathrm{v}_{2}\right)$ and ${ }^{1} A_{1 g}(D)-{ }^{1} E_{g}(G)\left(v_{3}\right)$, respectively [21].

\subsubsection{Copper(II) Complexes}

The magnetic moment of the $\mathrm{Cu}(\mathrm{II})$ complexes at room temperature lie in the range $1.90-1.96$ B.M corresponding to one unpaired electron. The complexes may be considered to possess a tetragonal geometry.

The electronic spectra copper (II) complexes Figure 5 display three bands (Table 2), in the $9987-10,560(\varepsilon=$ 48 - $\left.49 \mathrm{~L} \cdot \mathrm{mol}^{-1} \cdot \mathrm{cm}^{-1}\right) 15,991-16,384 \quad(\varepsilon=58$ $\left.\mathrm{L} \cdot \mathrm{mol}^{-1} \cdot \mathrm{cm}^{-1}\right) 28,057-29,514 \quad(\varepsilon=149-151$ $\mathrm{L} \cdot \mathrm{mol}^{-1} \cdot \mathrm{cm}^{-1}$ ) ranges. These bands corresponding to the transitions $B_{1 g}-{ }^{2} A_{1 g}\left(d_{x}^{2}-y^{2}-d_{z}^{2}\right) v_{1}$,

${ }^{2} B_{1 g}-{ }^{2} B_{2 g}\left(d_{x}^{2}-y^{2}-d_{z y}\right) v_{2}$ and

${ }^{2} B_{1 g}-{ }^{2} E_{g}\left(d_{x}^{2}-y^{2}-d_{z y}, d_{y z}\right) v_{3}$, respectively [22,23].

E.p.r. spectra of the $\mathrm{Cu}(\mathrm{II})$ complexes Figure 6 were recorded, at room temperature, as polycrystalline samples and in DMSO solution, on the X-band at $9.3 \mathrm{GHz}$ under the magnetic field strength 3400 G. Polycrstalline spectra show a well-resolved anisotropic broad signal [20].
The analysis of spectra give $\mathrm{g}_{<<}=2.20-2.26$ and ${ }^{\mathrm{g}}{ }_{\perp}=$ 2.06 - 2.10 (Table 3). The trend $\mathrm{g}_{<<}>\mathrm{g} \perp 2.0023$, observed for the complexes, under study, indicate that the unpaired electron is localized in the $d_{x}^{2}-y^{2}$ orbital of the $\mathrm{Cu}(\mathrm{II})$ ion and the spectral figures and characteristic for the axial symmetry, Tetragonally elongated geometry is thus confirmed for the aforesaid complexes [24,25].

$\mathrm{G}=\left(\mathrm{g}_{<<}-2\right) /\left({ }_{\perp}{ }_{\perp}-2\right)$, which is the measurement of the exchange interaction between the metal centers in a solid sample of the complex has also been calculated. According to Hathaway and Billing [26] if $\mathrm{G}>4$, the exchange interaction is negligible but $\mathrm{G}<4$ indicates the considerable exchange interaction in the solid complexes. The complexes reported here gives the ' $G$ ' value in the range $2.43-2.60$, which is $>4$, indicating exchange interaction in the solid complexes.

\subsection{Ligand Field Parameters}

Various ligand field parameters were calculated for the complexes and are listed in Table 4.

The Values of Dq in Co(II) complexes were calculated from transition energy ratio diagram using the $\mathrm{v}_{3} / \mathrm{v}_{2}$ ratio [27]. Our results are in agreement with the complexes reported earlier [28]. The Nephelauzetic parameter $\beta$ was readily obtained by using the relation: $\beta=\mathrm{B}$ (Com$\mathrm{plex} / \mathrm{B}$ (free ion), where B (free ion) for $\mathrm{Mn}(\mathrm{II})$ is 786 $\mathrm{cm}^{-1}$, for $\mathrm{Ni}(\mathrm{II})$ is 1041 and for $\mathrm{Co}(\mathrm{II})$ is $1120 \mathrm{~cm}^{-1}$ [29]. The values of $\beta$ lie in the range of $0.46-0.070$ range. The values of $\beta$ and indicate the appreciable covalent character of metal ligand " $\sigma$ " bond. The graphical information contained in the Orgel energy leveldiagram $[18,19]$. Parameter B and C are a liner combination of certain Columb's exchange integral and are generally treated as empirical parameters obtained from the spectra of free ions. In $\mathrm{Mn}$ (II) the values of B and C are calculated from the second transition because and depend on $\mathrm{B}$ and $\mathrm{C}$ parameters. The calculated values of the ligand field parameters are given in Table 4. Slater condon shortly parameters $F_{2}$ and $F_{4}$ are related to the Recah 
Table 3. EPR spectral data of the complexes.

\begin{tabular}{cccccccccc}
\hline Complex & & \multicolumn{3}{c}{ Date as polycrystalline sample } & \multicolumn{3}{c}{ Date in DMF solution } \\
\hline & Temp. & $g_{11}$ & $g_{1}$ & $g_{\text {iso }}$ & G & $g_{11}$ & $g_{1}$ & $g_{\text {iso }}$ & G \\
\hline$\left[\mathrm{Mn}(\mathrm{L}) \mathrm{Cl}_{2}\right]$ & RT & -- & -- & 2.0052 & -- & -- & -- & 2.0015 & -- \\
{$\left[\mathrm{Mn}(\mathrm{L})\left(\mathrm{NO}_{3}\right)_{2}\right]$} & RT & -- & -- & 2.0094 & -- & -- & -- & 2.0018 & -- \\
{$\left[\mathrm{Co}(\mathrm{L}) \mathrm{Cl}_{2}\right]$} & LNT & 2.418 & 2.0098 & 3.75787 & -- & 2.419 & 2.0178 & 3.7642 & -- \\
{$\left[\mathrm{Co}(\mathrm{L})\left(\mathrm{NO}_{3}\right)_{2}\right]$} & LNT & 2.358 & 2.0175 & 3.70267 & -- & 2.3396 & 2.0060 & 3.6793 & -- \\
{$\left[\mathrm{Cu}(\mathrm{L}) \mathrm{Cl}_{2}\right]$} & RT & 2.0930 & 2.0598 & 3.4662 & 0.87797 & 2.1345 & 2.0715 & 3.5155 & 0.8309 \\
{$\left[\mathrm{Cu}(\mathrm{L})\left(\mathrm{NO}_{3}\right)_{2}\right]$} & RT & 2.119 & 2.668 & 3.89767 & 0.63063 & 2.0810 & 2.6896 & 3.87407 & 0.6626 \\
\hline
\end{tabular}

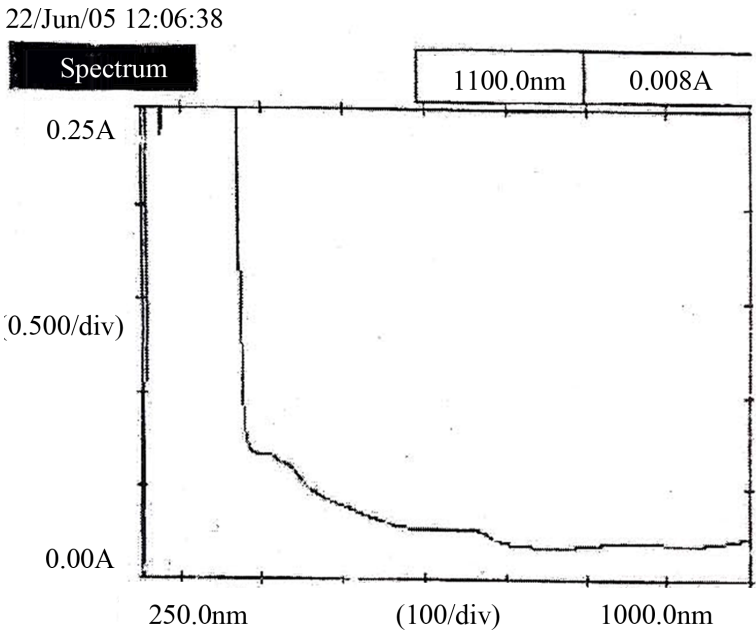

Figure 4. UV Spectrum of $\left[\mathrm{Ni}\left(\mathrm{L}^{5}\right)\left(\mathrm{NO}_{3}\right)_{2}\right]$.

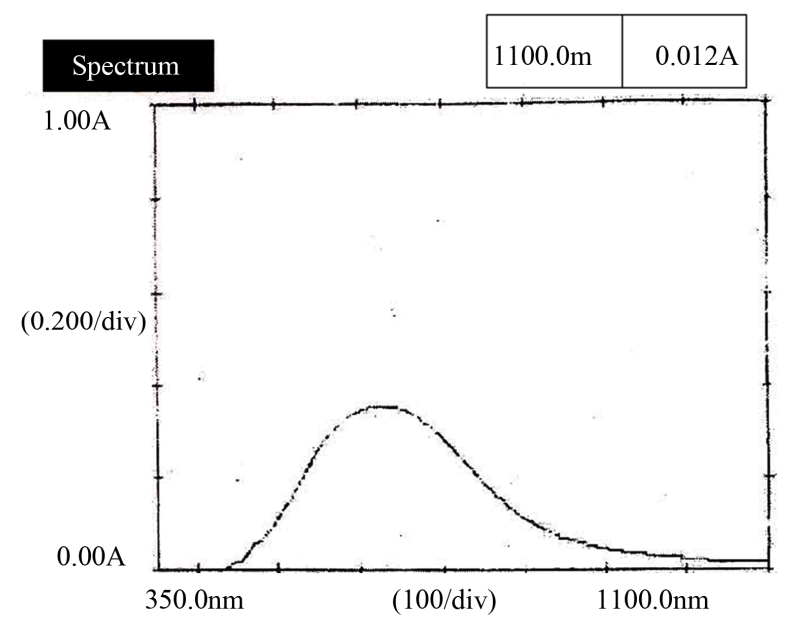

Figure 5. UV Spectrum of $\left[\mathrm{Cu}\left(\mathrm{L}^{5}\right)\left(\mathrm{NO}_{3}\right)_{2}\right]$.

parameter $\mathrm{B}$ and $\mathrm{C}$ as: $\mathrm{B}=\mathrm{F}_{2}-5 \mathrm{~F}_{4}$ and $\mathrm{C}=35 \mathrm{~F}_{4}$. The effect of covalence is to reduce the positive charge on the metal ion as consequence of the inductive effect to the ligand with reduced positive charge, the radial extension of the $d$ orbital increases, this decreases the electronelectron repulsion, lowering the energy of the ${ }^{3} \mathrm{P}$ states.

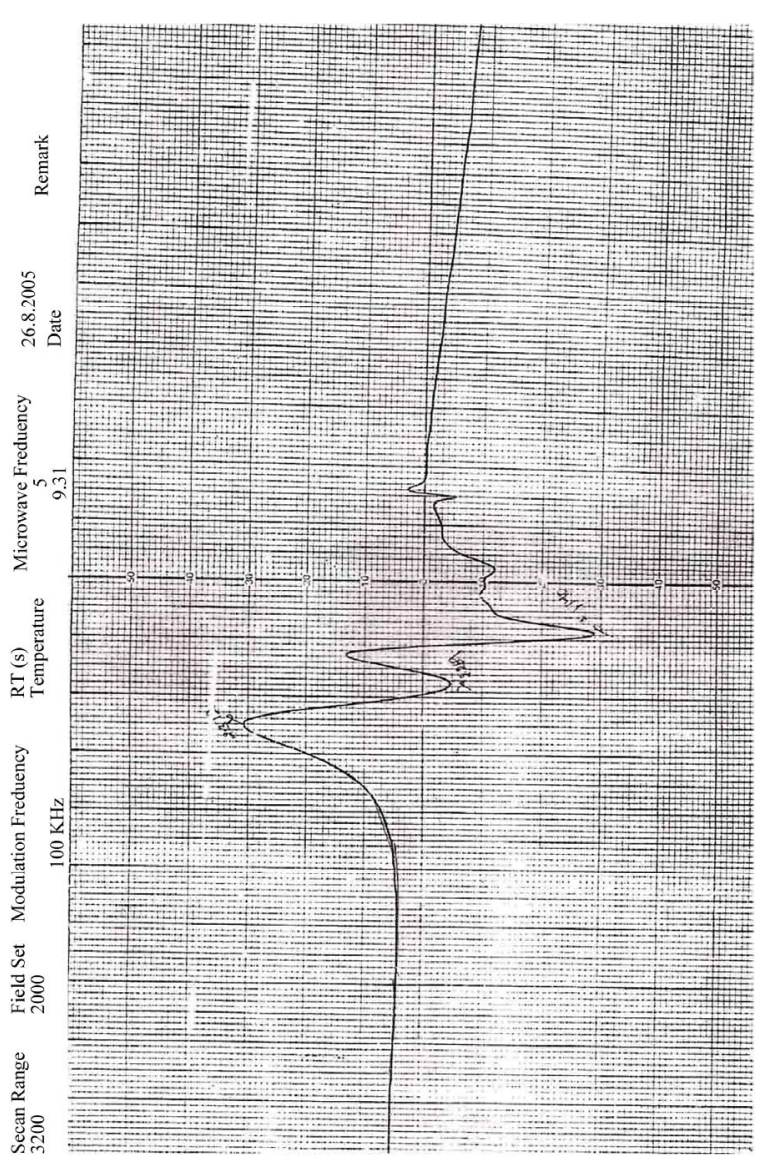

Figure 6. EPR Spectrum of $\left.\left[\mathrm{Cu}\left(\mathrm{L}^{5}\right) \mathrm{SO}_{4}\right)\right]$.

Table 4. Ligand field parameters of the complexes.

\begin{tabular}{ccccc}
\hline Complex & $\mathrm{Dq}\left(\mathrm{cm}^{-1}\right)$ & $\mathrm{B}\left(\mathrm{cm}^{-1}\right)$ & $\beta$ & $\begin{array}{c}\mathrm{LFSE} \\
\left(\mathrm{kJ} \cdot \mathrm{mol}^{-1}\right)\end{array}$ \\
\hline$\left[\mathbf{M n}(\mathbf{L}) \mathbf{C l}_{2}\right)$ & 1851.85 & 613.70 & 0.75 & \\
{$\left[\mathbf{M n}(\mathbf{L})\left(\mathbf{N O}_{3}\right)_{2}\right.$} & 1891.08 & 518.25 & 0.61 & \\
{$\left[\mathbf{C o}(\mathbf{L}) \mathbf{C l}_{2}\right]$} & 990 & 501 & 0.53 & 121.50 \\
{$\left[\mathbf{C o}(\mathbf{L})\left(\mathbf{N o}_{3}\right)_{2}\right]$} & 951 & 510 & 0.50 & 133.75 \\
{$\left[\mathbf{N i}(\mathbf{L}) \mathbf{C l}_{2}\right)$} & 1650 & 750 & 0.66 & 231.90 \\
{$\left[\mathbf{N i}(\mathbf{L})\left(\mathbf{N o}_{3}\right)_{2}\right]$} & 1581 & 718 & 0.80 & 237.23 \\
\hline
\end{tabular}




\section{XRD}

The XRD spectra have been recorded for all the complexes. For all the complexes the value of $d$ is found to be same. This indicates that the complexes have same geometry. Hence on the basis elemental analyses, magnetic moment molar conductance, IR, EPR and X-ray diffraction pattern following structure of the complexes may be suggested Figures 7(a) and (b).

\section{CONCLUSION}

Complexes of $\mathrm{Mn}(\mathrm{II}), \mathrm{Co}(\mathrm{II}), \mathrm{Cu}(\mathrm{II}) \& \mathrm{Ni}(\mathrm{II})$ with tetradentate macrocyclic ligand have been prepared and characterized. The proposed study reveled six coordinated octahedral geometry for $\mathrm{Co}(\mathrm{II}), \mathrm{Mn}(\mathrm{II})$ and square planer geometry for $\mathrm{Ni}(\mathrm{II})$ and tetragonal geometry for $\mathrm{Cu}$ (II) complexes. Various ligand fields and bonding parameters have been calculated and discussed.

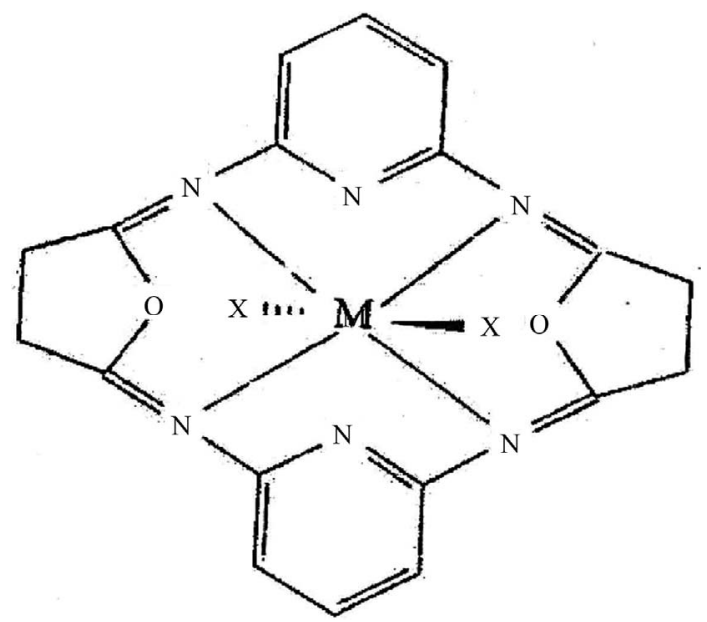

(a)

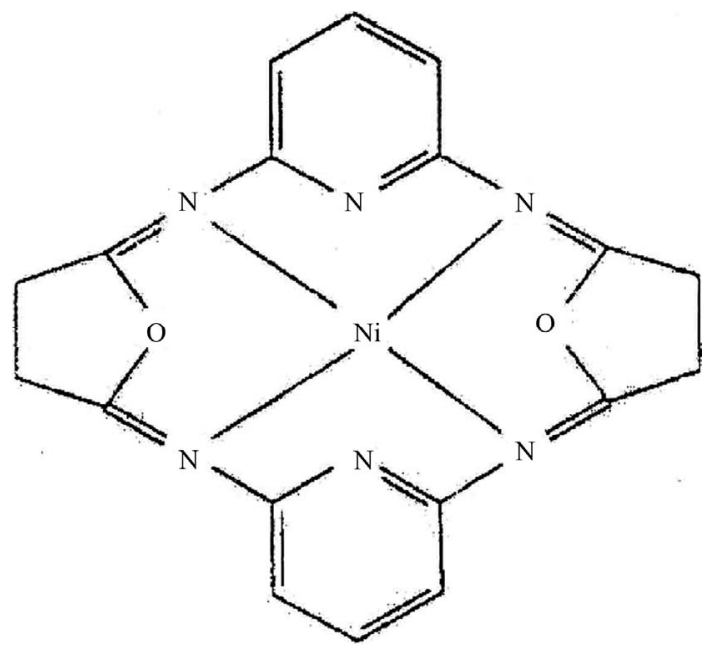

(b)

Figure 7. (a) $\left[\mathrm{M}(\mathrm{L}) \mathrm{X}_{2}\right] \mathrm{X}=\mathrm{Cl}^{-1}, \mathrm{NO}_{3}^{-}, \mathrm{CH}_{3} \mathrm{COO}^{-}$ $\mathrm{M}=\mathrm{Mn}(\mathrm{II}), \mathrm{Co}(\mathrm{II})$ and $\mathrm{Cu}(\mathrm{II})$; (b) $[\mathrm{Ni}(\mathrm{L})] \mathrm{X}_{2}, \mathrm{X}=\mathrm{Cl}^{-1}$.

\section{ACKNOWLEDGEMENTS}

Authors are thankful to UGC New Delhi for financial assistance and I.I.T. Bombay for recording EPR spectra.

\section{REFERENCES}

[1] Mishra, D., Naskar, S.D., Drew, M.G.B. and Chatto Phadhyay, S.K. (2006) Synthesis, spectroscopic and redox properties of some ruthenium (II) thiosemi carbozone complexes: Structural description of four of these complexes. Inorganica Chimica Acta, 359, 585-592. http://dx.doi.org/10.1016/j.ica.2005.11.001

[2] El-Wahab, Z.H.A., Mashaly, M.M., Salman, A.A., et al. (2004) Co(II), Ce(III) and Uo2 (VI) bis-salicylatothiosemicarbazide complexes: Binaryt and ternary complexes thermal studies and antimicrobial activity. Spectrochimica Acta Part A, 60, 2861-2873.

[3] Kolocouris, Dimas, K., pannecouque, C., et al. (2002) New 2-C1-adamantrylcarbopnye) pysidine and 1-acetyladamantane thiosemicarbozones-thicorbonohydrazones cell growth inhibitory, antiviral and antimicrobal activity evaluation. Bioinorganic and Medicinal Chemistry Letters, 12, 723-727.

[4] Argiielles, R., Touson-Touceda, M.C.P., Cao, R., et al. (2009) Complexes of 2-acetyl-y butysolactone and 2furancarbaldehyde thiosemi carbazones: Antibacterial and antifungal activity. Journal of Inorganic Biochemistry, 103, 35-42.

[5] Ainscough, E.W., Brodie, A.M., Denny, W.A. Finlay, G.J. and Ranford, J.D. (1998) Nitrogen, sulfar and oxygen donor adducts with copper (II) complexes of antitumer 2-formylphridinethiosemicarbazone analogs physicoche- mical and cytotoxic studies. Journal of Inorganic Bio- chemistry, 70, 175-185. http://dx.doi.org/10.1016/S0162-0134(98)10011-9

[6] Kothari, R. and Sharma, B. (2011) Synthesis, characterization and in-vitro antimicrobial investigation of some transition metal complexes with the Schiff base of aromatic aldehyde. Journal of Chemistry \& Chemical Sciences, 1, 158-163.

[7] Chandra, S. and Kumar, A. (2013), Spectral Thermal and Morphological studies of chromium nanoparticals. Spectrochimica Acta Part A, 102, 25-255.

[8] Chandra, S., Bargujar, S., Nirwal, R. and Yadav, N. (2013) Synthesis, spectral characterization and biological evaluation of copper(II) and nickel(II) complexes with thiosemicarbazones derived from a bidentate Schiff base. Spectrochimica Acta Part A, 106, 91-98.

[9] Chandra, S. and Ruchi (2013) Synthesis, spectroscopic characterization molecular modeling and antimicrobial activities of $\mathrm{Mn}(\mathrm{II}), \mathrm{Co}(\mathrm{II}), \mathrm{Ni}(\mathrm{II}), \mathrm{Cu}(\mathrm{II})$ complexes containing the tetradentate aza Schiff base ligand. Spectrochimica Acta Part A, 103, 338-348.

[10] Lindog, L.F. (1990) The chemistry of Macrocylic ligand complexes. Cambridge University Press, Cambridge.

[11] Rastogi, A., Anurag and Narayan, R. (2011) Ni(II) and $\mathrm{Co}$ (II) complexes of azamacrocycles drived from trichloromethane. Journal of Coordination Chemistry, 64, 875-892. 
http://dx.doi.org/10.1080/00958972.2011.558192

[12] Chandra, S. and Gupta, L.K. (2005) Electronic, EPR, Magnetic and mass spectral studies of mono and homo binuclear $\mathrm{Co}(\mathrm{II})$ and $\mathrm{Cu}(\mathrm{II})$ complexes with a novel macrocyclic ligand. Spectrochimica Acta Part A, 62, 11021106.

[13] Chandra, S. and Gupta, L.K. (2005) Mass, EPR, IR, electronic studies on newly synthesized macrocyclic ligand $\&$ its trasition metal complexes. Spectrochimica Acta Part A, 62, 1125-1130.

[14] Chandra, S. and Sharma, S.D. (2002) Cr(III), Mn(II), $\mathrm{Co}(\mathrm{II}), \mathrm{Ni}(\mathrm{II}), \mathrm{Cu}(\mathrm{II})$, and $\mathrm{Pd}$ (II) complexes of $12 \mathrm{mem}-$ berd tetraaza $\left(\mathrm{N}_{4}\right)$ macrocyclic ligand. Transition Metal Chemistry, 27, 732-735. http://dx.doi.org/10.1023/A:1020309322470

[15] Raman, N. (2009) Synthesis, spectral charactrization, in vitro antimicrobial evaluation and DNA cleavage studies of few macro cyclic complexes. Journal of the Chemical Society, 86, 1143-1149.

[16] Chandra, S. and Gupta, L.K. (2004) Mass, IR, electronic and EPR spectral studies on transition Metal complexes with a new tetradentate 12 Membued new Macrocyclic ligand. Spectrochimica Acta Part A, 60, 3079. http://dx.doi.org/10.1016/j.saa.2004.01.030

[17] Chandra, S. and Gupta, L.K. (2004) Spectroscopic, characterization of tetradentate Macrocyclic ligand and its transition metal complexes. Spectrochimica Acta Part A, 60, 2767. http://dx.doi.org/10.1016/j.saa.2004.01.015

[18] Shakir, M., Varkey, S.P. and Hameed P.S. (1993) Synthesis characterization \& antifungal studies of some tetra macrocyclic complexes. Polyhedron, 12, 2775.

[19] Rao, C.R.K. and Zacharias, P.S. (1997) Synthesis \& magnetic properties of dithiooxamide-Bridged Ni(II) complexes. Polyhedron, 16, 1201.

[20] Chandra, S. and Kumar, U. (2004) synthesis magnetic and spectral studies on $\mathrm{Cu}$ (II) complexes with bidentate thiosemicarbazone. Synthesis and Reactivity in Inorganic and Metal-Organic Chemistry, 34, 1417-1430.
[21] Chandra, S. and Gupta, K. (2001) synthesis \& spectal studies on $\mathrm{Cr}$ (III) Mn(II) Fe(III), Co(II), Ni(II) and $\mathrm{Co}(\mathrm{III})$ complexes of 14 membered and 16 membered microcyclic legand. International Journal of Quantum Chemistry, 40A, 775-779.

[22] Chandra, S. and Sharma, A.K. (2009) Ni(II) \& Cu(II) complexes with base legand 2,6 diascetyl pyridine bis (arbohydrzaon): Synthesis and I.R. mass ${ }^{1}$ HNMR electronic and EPR. Spectrochimica Acta Part A, 72, 851-857.

[23] Mohammad, G.G., Hindy, M.M., et al. (2005) synthesis characterzation and biological activity of some transition metals with schiff base derived from 2 thiphen carboxaldehyde and amino benzoic acid. s Spectrochimica Acta Part A, 62, 1140-1150.

[24] Chandra, S. and Kumar, U. (2004) spectroscopic characterization of $\mathrm{Co}(\mathrm{II})$ complexes of indoxyl N(4) methyl thiosemicarbazone. Spectrochimica Acta Part A, 60, 2825-2829.

[25] Guzar, S.H. and Qin-Han, J.I.N. (2008) Synthesis characterization and spectral studies of new $\mathrm{Co}$ (II) and $\mathrm{Cu}$ (II) complexes of pyrrolyl 1-2-carboxaldehyde isonicotinoyl hydrazone. Journal of Applied Sciences, 8, 2480-2485.

[26] Chandra, S., Raiza, S., Tyagi, M. and Gautam, A. (2007) Synthesis spectroscopic and antimicrobeal studies on bivalent $\mathrm{Ni}(\mathrm{II})$ and $\mathrm{Cu}(\mathrm{II})$ complexes of bis (thiosemicarbozone). Bioinorganic Chemistry and Applications, 7, Article ID: 51483.

[27] Lever, A.B.P. (1968) inorganic \& electronic spectroscopy. 1st Edition, Elsevier, Amesterdam, 249-360.

[28] Chandra, S. and Gupta, L.K. (2004) Spectroscopic studies on $\mathrm{Mn}(\mathrm{II}), \mathrm{Co}(\mathrm{II}), \mathrm{Ni}(\mathrm{II})$ and $\mathrm{Cu}(\mathrm{II})$ complexes with $\mathrm{N}$ doner tetradentate microcyclic ligand drived from ethylcinnamate moiety. Spectrochimica Acta Part A, 60, 2411.

[29] Chandra and Sangeetika S. (2002) Synthesis \& spectral studies on $\mathrm{Cu}(\mathrm{II}), \mathrm{Co}(\mathrm{II})$ complexes of macrocyclic ligand containing thiosemicarbazone moiety. International Journal of Quantum Chemistry, 41, 1629. 